\title{
STATE REGULATION OF INNOVATIVE EMPLOYMENT IN THE CONTEXT OF INNOVATIVE ENTREPRENEURSHIP DEVELOPMENT
}

\author{
Ihor Kuksa1, * Iryna Hnatenko², Olga Orlova-Kurilova ${ }^{3}$, Nataliia Moisieieva ${ }^{4}$, \\ Viktoriia Rubezhanska ${ }^{5}$
}

\author{
${ }^{1}$ Prof. Dr Sc. (Ekon). Luhansk National Agrarian University. Alchevskih str. 44. \\ Kharkiv.Ukraine.Tel.+380506475207.E-mail Igor.kuksa.23@gmail.com \\ ${ }^{2}$ Assoc. Prof. PhD of Econ. Kyiv National University of Technologies and Design. \\ Nemyrovycha-Danchenka Street 2. Kyiv. Ukraine. Tel.+380661076939. E-mail q17208@ukr.net \\ ${ }^{3}$ Assoc. Prof. PhD of Econ. Luhansk National Agrarian University. Alchevskih str. 44. \\ Kharkiv.Ukraine.Tel.+380506210239.E-mail orlovakur73@gmail.com \\ ${ }^{4}$ Assoc. Prof. PhD of Philosophy. Kharkiv Petro Vasylenko National Technical University of \\ Agriculture. Alchevskih str. 44. Kharkiv.Ukraine.E-mail n.i.moiseeval@gmail.com \\ ${ }^{5}$ PhD of Econ. Luhansk Taras Shevchenko National University. Gogol str. 1. Starobilsk. \\ Ukraine.Tel.+380953081789.E-mail rubezhiik@gmail.com
}

Received 3105 2019; Accepted 30062019

The basis for the development of an innovative economy in Ukraine is to ensure the functioning of innovative entrepreneurship. At the same time, the efficiency of enterprises is conditioned by the use of innovative types of employment, aimed at providing them with highly qualified specialists with the necessary level of motivation to work. In their turn, the processes of effective formation of innovative employment involve the control by the state authorities. The aim of the study is to develop the architectonics of the state regulation mechanism of the innovative employment in Ukraine. To achieve this goal, the following methods of scientific research were used: the method of statistical analysis; the method of comparison and synthesis; the abstract-logical method; the graphic method. According to the results of the study, the recommendations on implementation of the regulation mechanism of innovative employment in Ukraine were suggested for use in practical activity of public authorities.

Key words: innovative activity, innovative employment, innovative entrepreneurship, regulation mechanism of innovation employment, labor market.

JEL Codes E24, L26, O32, O38

\section{Introduction}

The development of modern socio-economic relations and ensuring sustainable progress in the economy as a whole envisage the large-scale introduction of innovations in various spheres of the society functioning, which allows to ensure the creation of the new techniques and technologies and upgrading of the existing ones, the development and production of competitive products and services, the distribution

Copyright (C) 2019 The Authors. Published by Vytautas Magnus University, Lithuanian Institute of Agrarian Economics. This is an open-access article distributed under the terms of the Creative Commons Attribution-NonCommercial 4.0 (CC BY-NC 4.0) license, which permits unrestricted use, distri-bution, and reproduction in any medium, provided the original author and source are credited. The material cannot be used for commercial purposes. 
of Ukrainian goods and services to global markets, efficient use of human resources in the business process.

The works of many Ukrainian and foreign scientists are devoted to the investigation of the innovations use in the process of economic development, as well as at the labor market and in the entrepreneurial activity. Thus, Yemelianenko (2015), Sandugey (2015), Ivanova (2013) determined the specifics of the manifestation of innovative forms of employment, their impact on the Ukrainian economy, and substantiated the institutional approaches to regulating these forms of employment. The general tendencies of the innovation labor market and obstacles to its formation in Ukraine were investigated by Petrova (2013).

The main obstacles and opportunities in running small business on the example of Poland and Lithuania are outlined in the scientific work Barczyk, Musiał, Žukovskis (2019). The work of Mukhalchenko (2018) is dedicated to the definition of the general problems of Ukraine related to the employment of the population and to the substantiation of directions for improving of their management. Lisogor (2016) substantiated the need to strengthen the innovative principles of the formation of the knowledge economy, which involves the introduction of technological innovations and enhancement of the creative nature of labor as a prerequisite for the emergence and spread of innovative employment. Schumpeter (1976) and Drucker (1993) emphasized the leading role of workers in the extending of the innovations in entrepreneurial activity, noting the source of innovations, along with economic factors, social and psychological factors of the innovator, which predetermine inventions, ideas and innovations.

Lipych, Volynets, Khilukha, Matviichuk, Semchuk (2018) offered the foundations for creating a system for stimulating innovation behavior and an innovation platform for the exchange of knowledge among industrial workers. The specific behaviors that managers need to use to stimulate the development of innovative ideas on the part of the individual employees were explored by Jong and Hartog (2007). Pal'ová and Vejačka (2018) conducted an analysis of employment in the EU countries on the success of the achievement of the level approved in the Europe 2020 strategy and the study of factors affecting employment in European countries. Zalk (2014) explored the role of production in stimulating economic growth and employment in South Africa and outlined direct and indirect links in the interaction between entrepreneurship and employment in the country. Bąk-Grabowska (2014) analyzed the level of self-employment in Poland from the point of view of the human resources management process at enterprises by the way of the outsourcing and collaboration with non-employed employees.

In justice to the research carried out, it should be noted that they do not reflect the features of the process of managing of the innovative employment and innovation entrepreneurship interaction. At the same time, the problem of optimal regulation of innovative employment requires the formation and implementation of a complex of measures aimed at its solution on the state level in particular. 
Therefore, the purpose of our research is to develop the architectonics of the state regulation mechanism of innovative employment in Ukraine. According to the mentioned goal, the research tasks are: to analyze the dynamics of Ukraine's indicators in the international ranking of countries according to the Global Competitiveness Index and the Global Index of Innovations; consider the foreign experience of state regulation of innovative employment; to propose recommendations for the implementation of a comprehensive mechanism for regulation of innovative employment in Ukraine.

Object of the research is innovative processes in the context of employment and entrepreneurship, subject of research is the state regulation of innovative employment.

In the process of scientific research, the following methods were used: the method of statistical analysis - for monitoring current trends and analyzing the state of the innovation development of Ukraine in relation to countries of the world; the method of comparison and synthesis - to study the foreign experience of state regulation of innovative employment; abstract-logical method - to formulate conclusions and implement theoretical generalizations on the level of innovation activity in Ukraine and the ways to increase it; graphic method - for visual presentation of theoretical and analytical material to reflect the main tendencies of innovation development in Ukraine.

Recommendations suggested by the research results may be used by public authorities in the process of implementation of innovation policy in the labor market in Ukraine in order to spread the use of innovative types of employment in entrepreneurial activity, which will stimulate the reduction of unemployment and increase of the general level of production.

\section{Research results and discussion}

One of the main characteristics of modern socio-economic, scientific and technical and production processes, which determine the general development of any state and its place in the system of international economic relations, is the level of innovation activity in the country. An objective assessment of the state of innovation development in Ukraine can be carried out by analyzing the dynamics of its indicators over a period of time in the international rating of countries according to the Global Competitiveness Index and the Global Innovation Index. The dynamics of Ukraine's position change according to the indexes for 2012-2018 is shown in Fig. 1. 
Ihor Kuksa, Iryna Hnatenko, Olga Orlova-Kurilova, Nataliia Moisieieva,

Viktoriia Rubezhanska. State regulation of innovative employment in the context of innovative entrepreneurship development

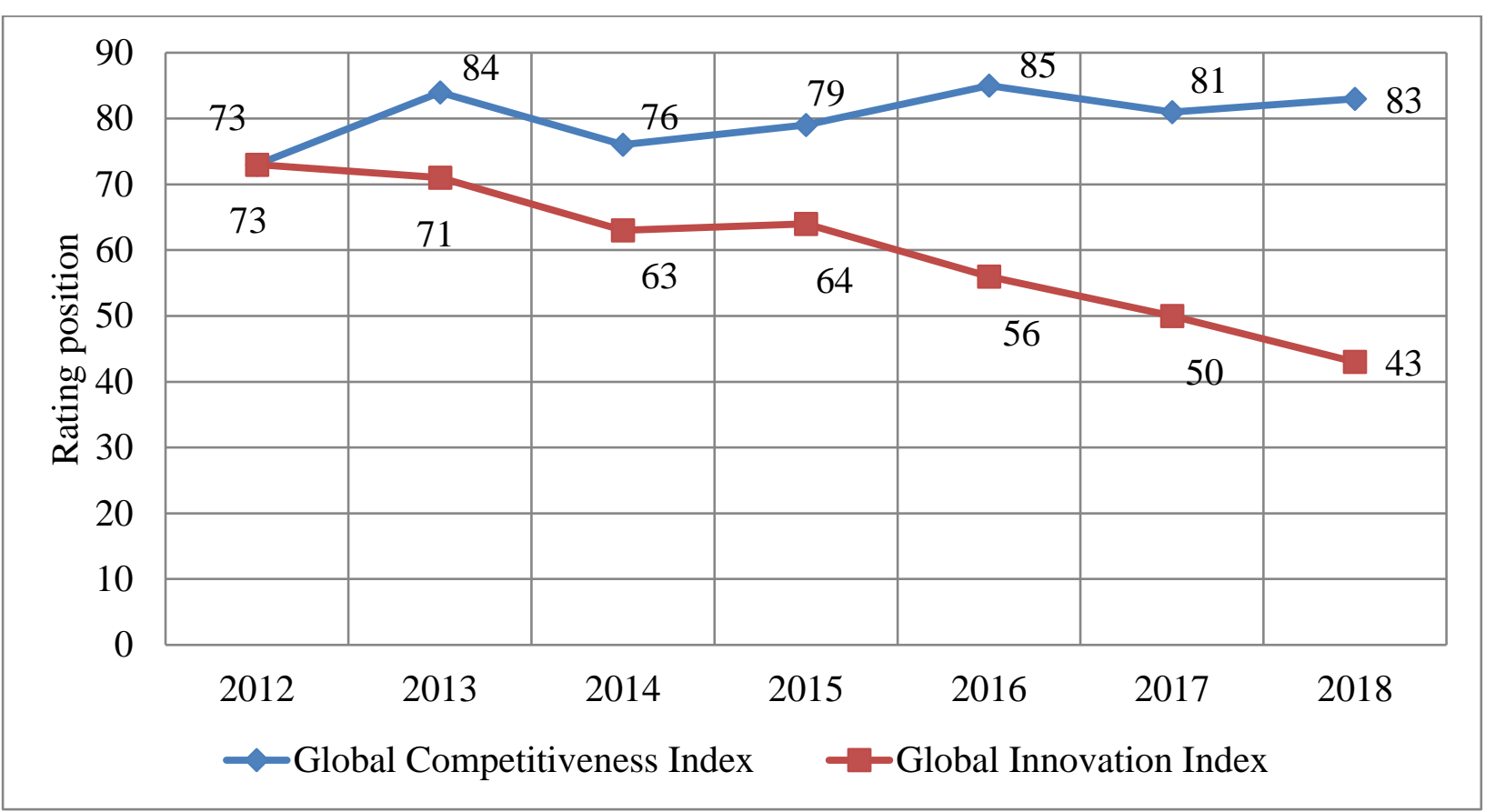

Fig.1 Ukraine's place in international ratings for 2012-2018

Based on the information shown in Fig. 1, it should be noted the gradual growth of the ranking of Ukraine among the countries of the world by the Global Innovation Index. Thus, Ukraine has improved its result by this index by 30 points within 6 years. However, at the same time, the distribution of countries according to the Global Competitiveness Index indicates the retaining of Ukraine's low positions and their deterioration by 2 points in 2018. The nearest neighbors of Ukraine in this ranking are the Dominican Republic (the 82nd place) and Macedonia (the 84th place).

In our opinion, the sub-index "Innovations", which is part of the Global Competitiveness Index, reflects the situation with the development and introduction of innovations to the Ukrainian economy in more detail. The positions of Ukraine by the components of the indicated sub-index during the period of 2012-2018, according to the Global Competitiveness Index, are reflected in the table. 1.

Table 1. Aggregated indices of the sub-index "Innovations" for Ukraine

\begin{tabular}{|l|c|c|c|c|c|c|}
\hline \multirow{2}{*}{ Index } & $\begin{array}{c}2012- \\
2013\end{array}$ & $\begin{array}{c}2013- \\
2014\end{array}$ & $\begin{array}{c}2014- \\
2015\end{array}$ & $\begin{array}{c}2015- \\
2016\end{array}$ & $\begin{array}{c}2016- \\
2017\end{array}$ & $\begin{array}{c}2017- \\
2018\end{array}$ \\
\cline { 2 - 7 } & \multicolumn{7}{|c|}{ Rating position } \\
\cline { 2 - 7 } & $\begin{array}{c}\text { of 144 } \\
\text { countries }\end{array}$ & $\begin{array}{c}\text { of 148 } \\
\text { countries }\end{array}$ & $\begin{array}{c}\text { of 144 } \\
\text { countries }\end{array}$ & $\begin{array}{c}\text { of 140 } \\
\text { countries }\end{array}$ & $\begin{array}{c}\text { of 138 } \\
\text { countries }\end{array}$ & $\begin{array}{c}\text { of 137 } \\
\text { countries }\end{array}$ \\
\hline $\begin{array}{l}\text { Sub-index } \\
\text { "Innovations" }\end{array}$ & 71 & 93 & 81 & 54 & 52 & 61 \\
\hline Innovation ability & 58 & 100 & 82 & 52 & 49 & 51 \\
\hline $\begin{array}{l}\text { Quality of research } \\
\text { institutes }\end{array}$ & 64 & 69 & 67 & 43 & 50 & 60 \\
\hline
\end{tabular}




\begin{tabular}{|l|c|c|c|c|c|c|}
\hline $\begin{array}{l}\text { Company expenses } \\
\text { for research and } \\
\text { development }\end{array}$ & 104 & 112 & 66 & 54 & 68 & 76 \\
\hline $\begin{array}{l}\text { Cooperation of } \\
\text { universities and } \\
\text { industry in research } \\
\text { and development }\end{array}$ & 69 & 77 & 74 & 74 & 57 & 73 \\
\hline $\begin{array}{l}\text { Public Procurement } \\
\text { of High-Tech } \\
\text { Products of }\end{array}$ & 25 & 46 & 48 & 29 & 29 & 25 \\
\hline $\begin{array}{l}\text { The presence of } \\
\text { scientists and } \\
\text { engineers }\end{array}$ & & 118 & 123 & 98 & 82 & 96 \\
\hline
\end{tabular}

According to the table 1 it should be noted that in this rating in 2018 there was a rapid decrease of Ukraine's position from 52nd to 61st place compared to the previous year. Such a sharp deterioration of the generalized rating position is due to a decrease in all components of the Index of Innovation. At the same time, the "Availability of Scientists and Engineers" indicator showed growth from the 29th to the 25th position. It is also worth noting the growth of another component of the Global Competitiveness Index - "Technological Readiness," which takes into account technological borrowing and the use of information and telecommunication technologies. By this rating position Ukraine ranked the 81st in 2018 (the 85th in the previous year), indicating that there was a certain technological potential for innovation.

On the basis of the analysis of Ukraine's rating positions on the above-mentioned indices, one can see that the existing diverse crisis prevents the development of an innovative economy and leads to a decrease in the global competitiveness indicators in relation to the other countries of the world.

In our opinion, the development and introduction of innovations both in the sphere of entrepreneurial activity and in the field of functioning of the labor market will contribute to increase the competitiveness of Ukraine in the international competitiveness rating. It should be noted that these spheres are inextricably linked and actively interact, since the use of innovative types of employment in entrepreneurial activity determines the efficiency of functioning and, accordingly, increase of profits of enterprises. In addition, the success of the use of innovative types of employment also depends on the efficiency of management of the indicated employment at the state level that is proved by the foreign experience of regulation in this area. For example, in the EU countries this is reflected in the following processes: expanding the practice of using flexible labor relations models, developing and implementing new preventive measures to combat unemployment, modernizing the taxation system, expanding the employment of older people, etc. In the United States, the state actively influences the field of employment by implementing education programs, training programs, by increasing the number and quality of jobs, by encouraging companies through tax breaks to create new workplaces and social insurance. Back in the 60s and 70s of the 
20th century, there were adopted the laws aimed at developing the intellectual characteristics of the workforce in the countries with a market economy. For example, in Japan since 1973, the law "On the intellectualization of society and the development of capabilities of the population" has been in force. The similar laws have been adopted in a number of other countries of the world (France, Germany, USA, etc.). In Ukraine, there is no perfect legal basis for regulation of employment, especially in the innovative sector of the economy. Therefore, taking into account the foreign experience of management and the peculiarities of functioning of the economic system of Ukraine in order to increase the general level of employment and promote the widespread use of its innovative types in entrepreneurial activity it is necessary to improve the labor legislation, to stimulate the investment of enterprises in the development of human capital, to coordinate the interests of all interested persons in the labor market, to improve the quality of education, to develop the intellectual potential of the population of the country, etc. In addition, it is important that this mechanism would be in line with the goals of the country's socio-economic system and would function on the principles of rational integrity, isolation and consistency of elements. Such a structure of the mechanism will ensure its stability, dynamism of development and adequacy to changing realities. Architectonics of the mechanism of state regulation of innovative employment is schematically reflected in Fig. 2

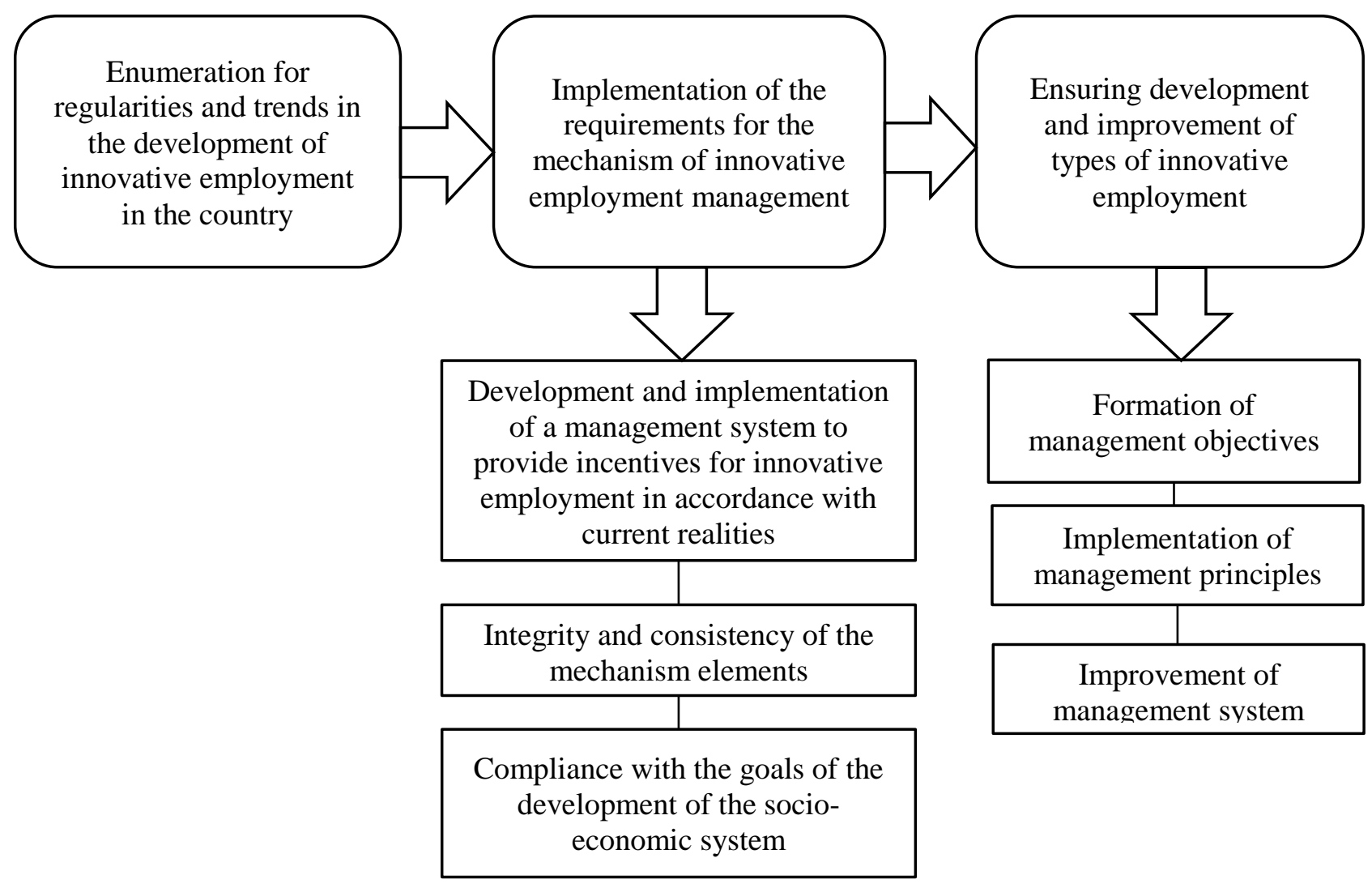

Fig. 2. Architectonics of the mechanism of state regulation of innovative employment 
An important task of the mechanism depicted in Fig. 2 is to promote the formation of new values, motivations, perspectives, innovations in the behavior of the labor market, mobility, support for key groups of workers, which under favorable conditions will form the potential of innovative employment. At the same time the most difficult task is to define and evaluate the results of management of innovative employment. In our opinion, as a result of management, a high level of employment should be ensured not by maintaining a large number of workers but by creating new workplaces, by the development of new forms of employment, and by increasing the competitiveness of workers in the labor market. The solving of these complex tasks should be addressed to the employment management institutes that operate at the state, regional levels and at the level of each individual enterprise.

\section{Conclusion}

Negative dynamics of Ukraine's positions in the international ratings during 20122018 necessitates the introduction of innovations in the field of entrepreneurial activity and in the labor market.

The world-wide experience of innovative employment regulation shows the significant shortcomings in the Ukrainian legislation regarding employment management in the innovation sector of the economy and the absence of a comprehensive mechanism for its regulation at the state level.

For the purpose of the effective implementation of a comprehensive mechanism for innovative employment regulation in Ukraine, it is advisable to recommend the following measures: to improve labor legislation aimed at promoting the employment development in an innovative direction; to promote the development of a system for monitoring new forms and types of employment; to coordinate the interests of all groups of stakeholders in the labor market and to develop joint actions to stimulate innovative types of employment; to make regionalization of the state employment policy by determining in the regions of the country the most popular types of innovative employment and their support, to ensure the optimum use of regional human resources; to improve the quality of education and the development of innovative potential of the population; to stimulate the processes of production updating and investing in the human capital development by the enterprises with the help of tax and monetary policy measures.

\section{References}

Bąk-Grabowska, D. (2014). Self-employment in Poland - the Perspective of Human Resources Management // Economics \& Sociology. Vol.7. No.1: 106-115. https://doi.org/10.14254/2071-789X.2014/7-1/10 [01 04 2019]

Barczyk, J., Musiał, W., \& Žukovskis, J. (2019). The barriers and opportunities to the development of small business in rural areas // Management Theory and Studies for Rural Business and Infrastructure Development. 41(1): 114-126. - https://doi.org/10.15544/mts.2019.11 [01 04 2019] 
De Jong, J., Hartog, D. (2007). How leaders influence employees' innovative behavior // European Journal of Innovation Management. Vol.10. No.1: 41-64. https://doi.org/10.1108/14601060710720546 [01 04 2019]

Drucker, P. (1993). Innovation and Entrepreneurship. - London: Harper Collins Publishers Ltd. 269 p.

Ivanova, L. (2013). Application of non-standard forms of labor in the modern labor market // Socio-economic research bulletin. Vol. 2 (49): 109-115.

Lipych, L., Volynets, I., Khilukha, O., Matviichuk, I., Semchuk Z. (2018). Model of management of the employees' innovative behavior at the industrial enterprises // Problems and $\begin{array}{llll}\text { Perspectives in Management. Vol.16. No.3: } & \text { 197-206. }\end{array}$ https://dx.doi.org/10.21511/ppm.16(3).2018.16 [01 04 2019]

Lisogor, L. (2016). Formation of the innovative employment under modernization economy and transformation of public relations // Economy and organization of management. Vol. 3(23): 8290 .

Mykhalchenko, H. (2018). The improvement of management of social and labor relations as one of the directions of economic development // Social and labour relations: theory and practice. Vol. 8(2): 56-68. - https://doi.org/10.21511/slrtp.8(2).2018.06 [01 04 2019]

Pal'ová, D., Vejačka, M. (2018). Analysis of Employment in EU According to Europe 2020 Strategy // Targets Economics and Sociology. Vol. 11(3): 96-112. - https://doi.org/10.14254/2071789X.2018/11-3/6 [01 04 2019]

Petrova, I. (2013). Innovation labor market: trends in Ukraine // Ukraine: aspects of labor. Vol. 5: 3-7.

Sanduhey, V. (2015). Formation of innovative type of employment in national economy // Economica. Vol. 30: 22-28.

Schumpeter, J. (1976). Capitalism, Socialism, and Democracy. - London: Allen and Unwin (Publishers) Ltd. 460 p.

The Global Innovation Index. Indicator rankings and analysis. (2018). https://www.globalinnovationindex.org/analysis-indicator [01 04 2019]

The Global Competitiveness Report 2017-2018. (2018). http://www3.weforum.org/docs/GCR2016-

2017/05FullReport/TheGlobalCompetitivenessReport2016-2017_FINAL.pdf [01 04 2019]

Yemel'yanenko, L. (2015). Formation and regulation of the newest forms of employment in Ukraine // Ukrainian Society. Vol. 1(52): 82-89.

Zalk, N. (2014). What is the role of manufacturing in boosting economic growth and employment in South Africa? - http://www.econ3x3.org/article/what-role-manufacturingboostingeconomic-growth-andemployment-south-africa [01 04 2019] 


\title{
INNOVATYVAUS UŽIMTUMO VALSTYBINIS REGLAMENTAS INNOVATYVOS İMONĖS PLE்TROS KONTEKSTE
}

\author{
Ihor Kuksa1, * Iryna Hnatenko², Olga Orlova-Kurilova ${ }^{3}$, Nataliia Moisieieva ${ }^{4}$, \\ Viktoriia Rubezhanska ${ }^{5}$ \\ ${ }^{1,3}$ Luhansko nacionalinis žemès ūkio universiteteas, Ukraina \\ ${ }^{2}$ Kijevo Nacionalinis technologiju ir dizaino universitetas, Ukraina \\ ${ }^{4}$ Kharkiv Petro Vasylenko nacionalinis technikos universitetas., Ukraina \\ ${ }^{5}$ Luhansko Taras Shevchenko nacionalinis universitetas, Ukraine
}

Pateikta 201905 3; Priimta 2019630

Inovatyvios ekonominès plètros Ukrainoje pagrindas yra užtikrinti novatorišką verslumo funkcionavimą. Tuo pat metu ịmonių efektyvumą lemia inovatyvių užimtumo būdų panaudojimas, siekiant suteikti rinkai aukštos kvalifikacijos specialistus, turinčius reikiamą motyvaciją dirbti. Savo ruožtu, efektyvaus novatoriško darbo formavimo procesai apima valstybės institucijų kontrolę. Tyrimo tikslas - plètoti Ukrainos novatoriško užimtumo valstybės reguliavimo mechanizmo architektoniką. Šiam tikslui pasiekti buvo naudojami tokie mokslinio tyrimo metodai: statistinès analizès metodas; palyginimo ir sintezès metodas; abstraktus-loginis metodas; grafinis metodas. Remiantis tyrimo rezultatais, rekomenduojamos rekomendacijos dẻl naujoviško užimtumo reguliavimo mechanizmo igyvendinimo Ukrainoje, siekiant jas panaudoti praktinèje valdžios institucijų veikloje.

Reikšminiai žodžiai: inovacine veikla, novatoriškas užimtumas, novatoriškas verslumas, inovaciju užimtumo reguliavimo mechanizmas, darbo rinka.

JEL kodai E24, L26, O32, O38.

\footnotetext{
* Autorius pasiteirauti
} 